\title{
Micromorphological Characterization of the Leaf and Rhizome of Agapanthus praecox subsp. praecox Willd. (Amaryllidaceae)
}

\author{
Olubunmi Josephine Sharaibi and Anthony Jide Afolayan \\ Medicinal Plants and Economic Development Research Centre, University of Fort Hare, Alice 5700, South Africa \\ Correspondence should be addressed to Olubunmi Josephine Sharaibi; bjlawal2002@yahoo.com
}

Received 9 May 2017; Revised 12 June 2017; Accepted 20 June 2017; Published 26 July 2017

Academic Editor: William K. Smith

Copyright (C) 2017 Olubunmi Josephine Sharaibi and Anthony Jide Afolayan. This is an open access article distributed under the Creative Commons Attribution License, which permits unrestricted use, distribution, and reproduction in any medium, provided the original work is properly cited.

\begin{abstract}
Agapanthus praecox subsp. praecox Willd. is a highly valued medicinal plant of family Amaryllidaceae. The genus Agapanthus has been difficult to classify into distinct species due to broad similar morphology of its members. Present taxonomic confusion in this genus and numerous medicinal uses of $A$. praecox necessitate its proper identification. The leaf and rhizome microcharacters were studied using scanning electron, light microscopy, and energy dispersive X-ray spectroscopy. Epidermal cells are polygonal having wavy anticlinal walls with mean adaxial length of $80.04 \pm 0.5 \mu \mathrm{m}$ and mean abaxial length of $85.33 \pm 0.6 \mu \mathrm{m}$. The leaf is amphistomatic with anomocytic stomata with mean pore length of $22.14 \pm 0.2 \mu \mathrm{m}$ on the adaxial and $15.02 \pm 0.3 \mu \mathrm{m}$ on the abaxial surface. The mean stomata densities on the adaxial and abaxial surfaces were $280.5 \pm 0.5 \mathrm{~mm}^{2}$ and $350.6 \pm 0.6 \mathrm{~mm}^{2}$. Trichomes and secretory ducts are absent on both surfaces. EDX spectroscopy showed that beryllium, carbon, oxygen, sodium, and silicon were present on both epidermal surfaces and rhizome while nitrogen, aluminum, and chlorine were detected only on the adaxial surface and sulphur was detected only in the rhizome.
\end{abstract}

\section{Introduction}

The genus Agapanthus established by L'Heritier in 1788 belongs to the family Amaryllidaceae and order Asparagales [1]. Leighton [2] revised the genus and recognized ten species: four evergreen species which are A. africanus (L.) Hoffmanns, A. comptonii F.M. Leight, A. praecox Willd., and A. walshii L. Bolus and six deciduous species, namely, A. campanulatus F.M. Leight, A. caulescens Spreng, A. coddii F.M. Leight, A. dyeri F.M. Leight, $A$. inapertus (L. Bolus) F.M. Leight, and A. nutans F.M. Leight. However, based on the nuclear DNA content and pollen morphology as well as vitality, Zonneveld and Duncan [3] recognized six species in total comprising of two evergreen species which are A. africanus (L.) Hoffmanns and A. praecox Willd. and four deciduous species, A. campanulatus F.M. Leight, A. caulescens Spreng, A coddii F.M. Leight, and $A$. inapertus (L. Bolus) F.M. Leight. The genus has been difficult to classify due to high rate of hybridization within member species which has led to array of garden hybrids with similar macromorphological features [4]. This accounts for the numerous misidentifications of the members of this genus.

Agapanthus praecox is an evergreen species of genus Agapanthus; it is commonly called blue lily, agapanthus, Africa lily, or lily of the Nile. It is an extremely variable species consisting of three subspecies: subsp. praecox, subsp. orientalis, and subsp. minimus. It is a rhizomatous perennial herb with a large basal tuft of dark green shiny leaves. The leaves are linear, strap-like, and $20-80 \mathrm{~cm}$ long by $2-6 \mathrm{~cm}$ wide. The blue to violet flowers are clustered in an umbellate inflorescence, $10-15 \mathrm{~cm}$ across, which is held high above the leaves on a stout shiny stalk to $1 \mathrm{~m}$ high. The individual flowers have 6 tepals, $4-6 \mathrm{~mm}$ long, and 6 stamens and 3 carpels with greenish capsules as fruits (Figure 1).

It is one of the widely used and highly valued medicinal plants in South African folkloric medicine. A. praecox is considered a plant of fertility and pregnancy; it is used with other plants taken during pregnancy to prevent complications, augment labour, and ensure delivery of healthy child [5]. It is 


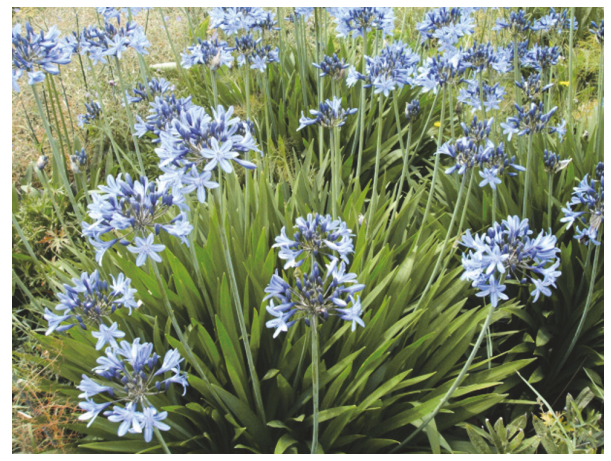

FIGURE 1: Morphological features of Agapanthus praecox showing the leaves and the umbel inflorescence.

also used by the traditional healers for the treatment of heart disease, paralysis, coughs, colds, and chest discomforts [6]. The root's decoction is given to sheep and goats as antidiarrhoea [7]. It possesses anti-inflammatory, antioedema, antitussive, immunoregulatory, antibacterial, antifungal, and antitumor properties [5]. The leaves are used to hold dressings in place and wound around wrists to bring down fevers [8]. Koduru et al. [9] also reported the anticancer potential of the root infusion. Pooley [10] stated that "bathing the newborn baby with the decoction of $A$. praecox makes them strong, keeps them free from bowel problems, and prevents crusts on the head." It was listed among the plant species traditionally used in Southern Africa for the treatment of various central nervous system-related ailments [11].

Medicinal plants are good sources of therapeutic drugs for the treatment and management of various ailments and diseases. Diversity, flexibility, easy accessibility, relative low cost, low levels of technological input, and relative low side effects are some of the positive features of traditional medicine [12]. However, one of the major setbacks in traditional medicine is the species misidentification of the constituents of these herbal medicines. The substitution of the medicinal plants with closely related species poses the problem of adulteration in the herbal products which could be fatal to the consumers. Investigating the morphological and anatomical characters of closely related species is an indispensable tool for the identification of the medicinal herbs [13]. Stuessy [14] emphasized the importance of anatomical characters in differentiating plant species.

The broad similar morphological characteristics within the members of the genus Agapanthus have led to substitution of $A$. praecox subsp. praecox with other closely related species and this has resulted in adulteration of the herbal products. Species misidentification of herbal drugs due to broad similarity in the morphological features of the medicinal plants and closely related species is common in Africa [15]. The numerous medicinal uses of Agapanthus praecox subsp. praecox and present taxonomic status of genus Agapanthus necessitate its proper identification.
Micromorphological characters studies are significant research tools in plant taxonomy; their applications in the identification and delimitation of plant species as well as in resolving taxonomic problems among critical species and genera have been recognized [13]. Trichomes are epidermal appendages that are highly varied in plants; their morphological diversity and distribution have emerged as important supportive taxonomic tools useful in delimiting plant species [16]. Stomata that are highly characteristic of the epidermis occur in widely divergent parts of the plants including common foliage leaves. Variations in stomata type, size, abundance, length, and density are taxonomically important characters that have been recognized as species specific and are used as significant parameters in the angiosperm taxonomy as well as in phylogenetic studies [17].

In view of the medicinal importance of Agapanthus praecox and the present taxonomic confusion in the genus Agapanthus; this study was designed to evaluate the microcharacters of the leaf and rhizome of Agapanthus praecox with a view to contributing to the knowledge of the genus and generating data to enhance the proper identification and classification of this species.

\section{Materials and Methods}

2.1. Plant Collection. Fresh plants of Agapanthus praecox subsp. praecox were collected from the University of Fort Hare, Alice Campus, South Africa, in June, 2016. The plant was identified by Dr. OJ Sharaibi and a voucher specimen (SHAMed 2016/07) was deposited in Giffen's herbarium of the Department of Botany, University of Fort Hare.

2.2. Light Microscopy. The leaf epidermal peels were obtained from the adaxial and abaxial surfaces of fresh matured leaves. They were stained with $1 \%$ Safranin-O and dehydrated by concentration series of ethanol. They were mounted on the glass slide and observed under a Zeiss light microscope (Axiovert 40). The photomicrographs were taken with a digital camera (DCM 510, $5 \mathrm{M}$ pixels, and CMOS chip) that was fitted to the light microscope. 
2.3. Scanning Electron Microscopy and Energy Dispersive XRay Spectroscopy. Squares of leaves and rhizomes of 4-6 $\mathrm{mm}$ thick were cut from the plant using razor blade. They were fixed for $12 \mathrm{~h}$ in $4 \%$ Glutaraldehyde with $\mathrm{PH} 7.3$ and were rinsed with $0.05 \mathrm{M}$ sodium cacodylate buffer ( $\mathrm{pH}$ 7.5). Each sample was later rinsed three times with distilled water before dehydration in a graded ethanol series (10-100\%) for 20 min per rinse. Samples were dried in a critical point drier and were mounted on aluminum stubs using twosided adhesive carbon tape coated with gold palladium (Elko IB-3 Ion Coater). The samples were examined at varying magnifications using JEOL (JSM-6390LV) scanning electron microscope (SEM) that was operated at $10-15 \mathrm{kV}$ accelerated voltage. The energy dispersive X-ray spectroscopy (EDX) followed the same procedures as in scanning electron microscopy. The elemental analysis of the samples was carried out using energy dispersive X-ray analyzer (Thermo Electron Corporation, 6733B-IUUSN, USA) connected to the scanning electron microscope. Electron images were captured using Noran system six imaging software.

Epidermal cell shape and thickness; stomata type, location, and distribution; trichomes shape, size, and distribution; the arrangement and position of accessory cells surrounding the guard cells as well as the type of phloem and xylem vessels present were the qualitative features considered. The quantitative features considered were stomata pore length, width, and density; subsidiary cell length, width, and density; trichomes density as well as the distance between the stomata $\left(\right.$ per $\mathrm{mm}^{2}$ ) on both the adaxial and abaxial epidermis.

\section{Results}

\subsection{Foliar Micromorphological Characters}

3.1.1. Leaf Epidermal Cells. These are polygonal in shape with wavy anticlinal walls on both the adaxial and abaxial surfaces. They were bigger and thicker on the abaxial surface than on the adaxial surface. Stomata were present on these surfaces but trichomes and secretory ducts were absent. The mean adaxial epidermal cell length was $80.04 \pm 0.5 \mu \mathrm{m}$ and the mean adaxial epidermal cell width was $20.13 \pm 1.2 \mu \mathrm{m}$ while the mean abaxial epidermal length was $85.33 \pm 0.6 \mu \mathrm{m}$ and the mean width was $17.78 \pm 0.5 \mu \mathrm{m}$. The number of epidermal cell counts ranges from 180 to 230 per $\mathrm{mm}^{2}$ on adaxial surface while the number of epidermal cell counts on abaxial surface ranges from 250 to 300 per $\mathrm{mm}^{2}$ (Figure 2).

3.1.2. Stomata. Both the abaxial and adaxial surfaces were characterized by anomocytic stomata which were more prevalent on the abaxial than the adaxial surface. The stomata lack subsidiary cells and were amphistomatically distributed on both surfaces. They were randomly arranged on both surfaces. The stomata were fully opened on both the adaxial and abaxial surfaces. The mean stomata pore length on the adaxial surface was $22.14 \pm 0.2 \mu \mathrm{m}$ and the mean adaxial stomata pore width was $21.05 \pm 1.0 \mu \mathrm{m}$ while the mean abaxial stomata pore length was $15.02 \pm 0.3 \mu \mathrm{m}$ with mean stomata pore width of $10.03 \mu \mathrm{m}$. The mean stomata density on the abaxial surface was $280.5 \pm 0.5 \mathrm{~mm}^{2}$ while the mean stomata density on the abaxial surface was $350.6 \pm 0.6 \mathrm{~mm}^{2}$. The guard cells length on both surfaces was $22.3 \pm 1.2 \mu \mathrm{m}$; the guard cells density on the adaxial surface was $345.7 \pm 0.7 \mathrm{~mm}^{2}$. The distance between the adaxial stomata was $45.6 \pm 0.8 \mu \mathrm{m}$ while the distance between the abaxial stomata was $21.2 \pm 0.4 \mu \mathrm{m}$ (Figures 3, 4, and 5).

3.2. Rhizome Microcharacters. The rhizome micromorphology of $A$. praecox was characterized with xylem vessels with helical secondary wall, that is, the protoxylem and some unusual outgrowths. At high magnifications, these outgrowths were similar to the trichomes but could not be categorized as such. Xylem vessels and tracheids made up the bulk of the vascular bundles and were more conspicuous than the phloem tissues. There are crystal deposits around the xylem vessels as shown in Figures 6 and 7.

3.3. Energy Dispersive X-Ray (EDX) Spectroscopy. The EDX analyzes some points of the adaxial and abaxial foliar epidermal layers and the rhizomes of $A$. praecox revealed the presence of carbon $(\mathrm{C})$, nitrogen $(\mathrm{N})$, sodium $(\mathrm{Na})$, magnesium $(\mathrm{Mg})$, phosphorous $(\mathrm{P})$, beryllium $(\mathrm{Be})$, silicon $(\mathrm{Si})$, potassium $(\mathrm{K})$, calcium $(\mathrm{Ca})$, oxygen $(\mathrm{O})$, and gold $(\mathrm{Au})$ assumed to be derived from the gold plating (Figures 8 and 9). The percentage atomic quantification of the elements as shown by EDX spectroscopy presented in Table 1 showed that beryllium $(\mathrm{Be})$, carbon $(\mathrm{C})$, oxygen $(\mathrm{O})$, sodium $(\mathrm{Na})$, and silicon $(\mathrm{Si})$ were present on both the abaxial and adaxial epidermal surfaces as well as in the rhizome. Nitrogen (8.42 \pm $2.19)$, aluminum $(0.34 \pm 0.04)$, and chlorine $(0.14 \pm 0.05)$ were detected only on the second point of the adaxial epidermal surface while sulphur was present only in the rhizome.

\section{Discussion}

The dart of information on the microcharacters of the genus Agapanthus necessitated this work. This study presents the microcharacters of A. praecox subsp. praecox that are of taxonomic importance. The presence of polygonal epidermal cells with wavy anticlinal walls in A. praecox subsp. praecox may be an important diagnostic character that may be helpful in delimiting Agapanthus species. It has been reported that variations in leaf epidermal cell size, shape, and thickness form the basis for the taxonomic position of some angiosperm families [18]. Stomata are highly characteristics of the leaf epidermis and occupy prominent position on the leaf surfaces. Da Silva et al. [19] stated that combining leaf epidermal data with the quantitative stomata data (density, length, and width) can enhance the information concerning species identification. Both the abaxial and adaxial surfaces of $A$. praecox are characterized by anomocytic stomata which are amphistomatically distributed and are more abundant on the abaxial than the adaxial surface. Anomocytic stomata may be a diagnostic character of the family Amaryllidaceae as earlier work by Awasthi et al. [20] reported the presence of anomocytic stomata in nineteen species of Amaryllidaceae studied. Stomata abundance on the abaxial than adaxial 
Table 1: Percentage atomic compositions of the elements in A. praecox foliar epidermal surfaces and the rhizome by EDX spectroscopy.

\begin{tabular}{|c|c|c|c|c|}
\hline Elements & Abaxial & Adaxial (1) & Adaxial (2) & Rhizome \\
\hline Beryllium & $25.03 \pm 0.86$ & $21.67 \pm 0.75$ & $17.69 \pm 0.56$ & $25.08 \pm 0.93$ \\
\hline Carbon & $68.06 \pm 1.09$ & $62.06 \pm 1.00$ & $52.38 \pm 1.18$ & $68.32 \pm 1.17$ \\
\hline Nitrogen & 0 & 0 & $8.42 \pm 2.19$ & 0 \\
\hline Oxygen & $6.01 \pm 0.36$ & $6.90 \pm 0.33$ & $11.13 \pm 0.72$ & $5.99 \pm 0.39$ \\
\hline Sodium & $0.09 \pm 0.04$ & $0.14 \pm 0.04$ & $0.06 \pm 0.05$ & $0.03 \pm 0.03$ \\
\hline Magnesium & $0.12 \pm 0.03$ & 0 & $0.11 \pm 0.03$ & $0.05 \pm 0.03$ \\
\hline Aluminium & 0 & 0 & $0.34 \pm 0.04$ & 0 \\
\hline Silicon & $0.05 \pm 0.04$ & $0.15 \pm 0.03$ & $0.43 \pm 0.05$ & $0.20 \pm 0.04$ \\
\hline Phosphorous & $0.08 \pm 0.07$ & 0 & $0.13 \pm 0.09$ & 0 \\
\hline Sulphur & 0 & 0 & 0 & $0.04 \pm 0.04$ \\
\hline Chlorine & 0 & 0 & $0.14 \pm 0.05$ & 0 \\
\hline Potassium & $0.10 \pm 0.05$ & $0.19 \pm 0.05$ & 0 & $0.13 \pm 0.05$ \\
\hline Calcium & $0.24 \pm 0.05$ & $0.21 \pm 0.05$ & 0 & $0.13 \pm 0.06$ \\
\hline Iron & $0.12 \pm 0.12$ & 0 & 0 & 0 \\
\hline Gold & $8.55 \pm 3.19$ & 0 & 0 & 0 \\
\hline
\end{tabular}

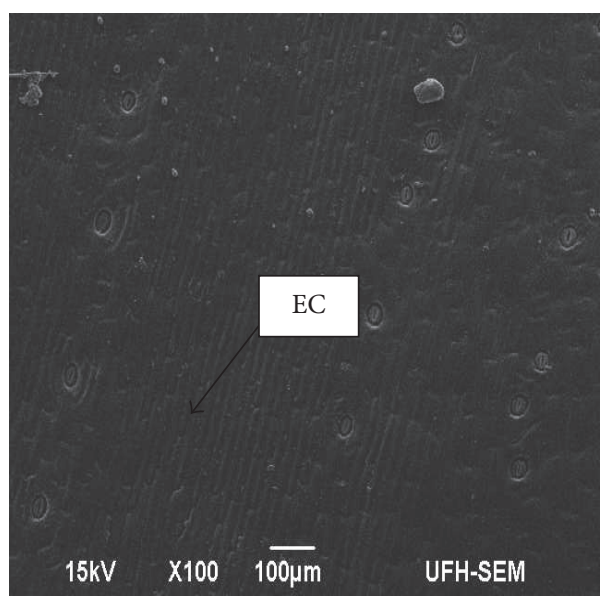

(a)

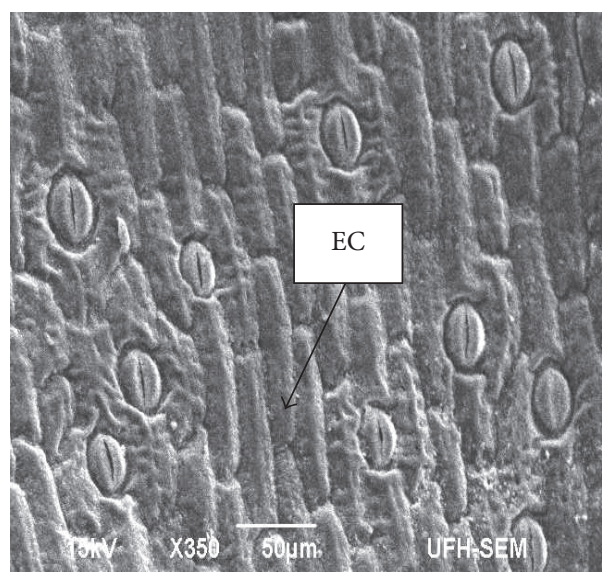

(c)

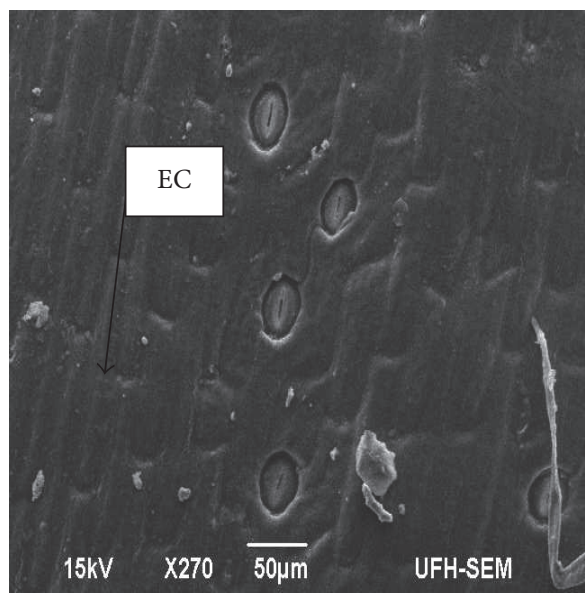

(b)

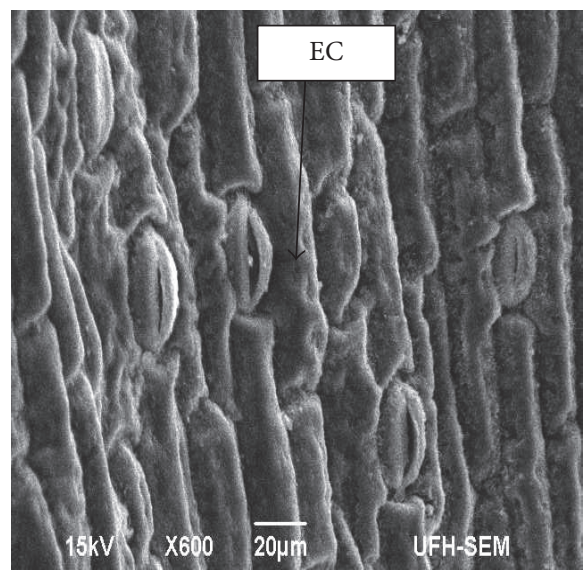

(d)

FIgURE 2: SEM micrographs of adaxial (a, b) and abaxial (c, d) epidermal cells of $A$. praecox subsp. praecox (EC = epidermal cells). 


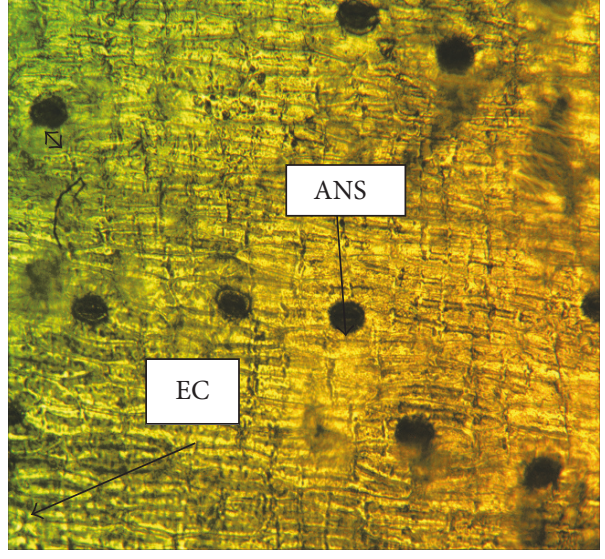

(a)

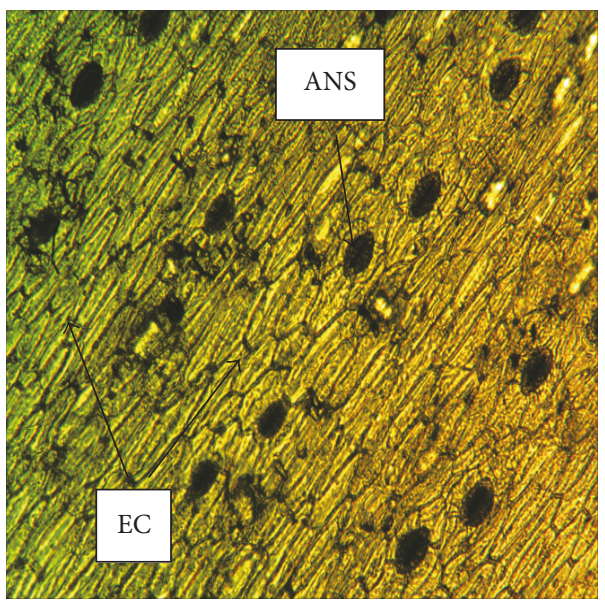

(c)

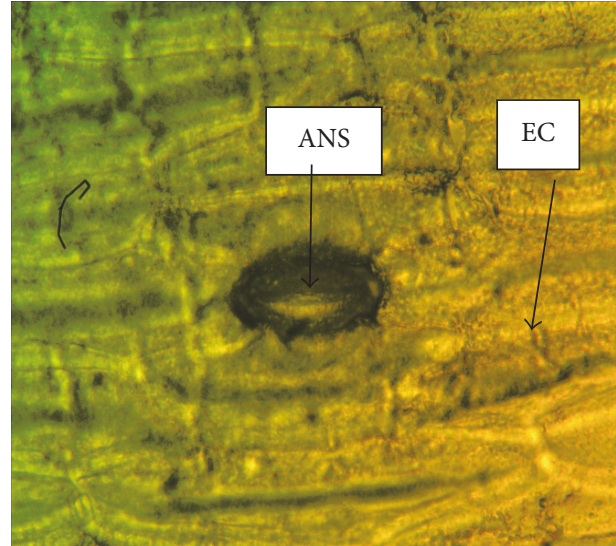

(b)

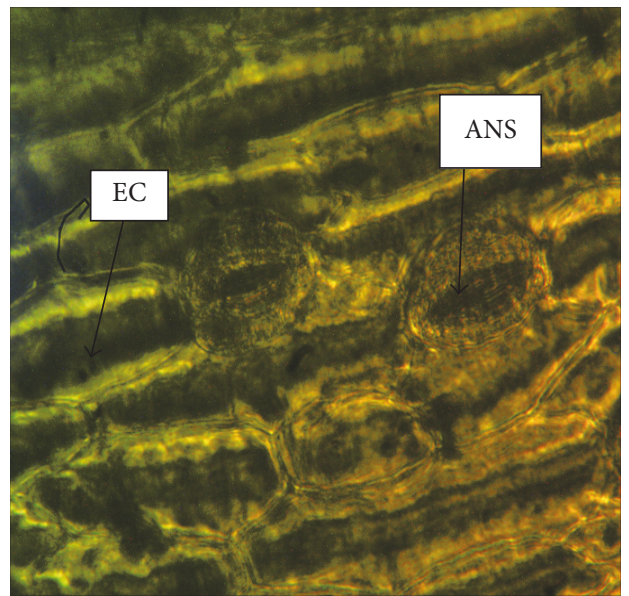

(d)

Figure 3: Photomicrographs of the light microscopy of adaxial (a, b) and abaxial (c, d) of A. praecox subsp. praecox showing anomocytic stomata and polygonal epidermal cells (EC = epidermal cells; ANS = anomocytic stomata).

epidermal surface of $A$. praecox subsp. praecox is a natural phenomenon in most angiosperms and an adaptation for water conservation [21]. Stomata size is consistently higher on the abaxial surface than on the adaxial surface; this can also be a mechanism to reduce transpiration.

The absence of trichomes and secretory ducts on the leaf epidermis of $A$. praecox may be an indication that the bioactive compounds are produced and stored in other tissues aside the trichomes in contradiction to Koduru et al. [22] who reported that bioactive compounds are produced or stored in the trichomes.

The scanning electron microscopy of the rhizome of A. praecox revealed the presence of vessels with helical thickened secondary wall. The presence of helical thickened secondary wall is typical of protoxylem. SEM micrographs showed the metaxylem pit membranes with numerous holes of various sizes. These holes may represent thin areas in the pit membrane, revealed only when portions of the pit membrane are shaved away by the sectioning. Crystals are estimated to occur in almost all the plants; they are found on the surfaces of roots, bark, stems, leaves, flowers, fruits, and seeds. They are categorized as sands, druses, styloids, raphides, prisms, and crystal sands and exhibit various sizes and shapes [23]. Their biological roles include calcium ionic balance, protection against herbivory, mechanical support to plants, and tolerance to heavy metal [24]. Deposition of the crystals on the surface of the xylem tracheary elements of $A$. praecox gives mechanical support to the plant in addition to water conduction. Also, since trichomes and secretory ducts are absent in A. praecox, most of the phytochemicals responsible for the therapeutic activities of $A$. praecox may be produced and stored in the xylem tracheary elements. The results of the EDX spectroscopy revealed that the major elements of the crystals present on the leaf and rhizome of $A$. praecox were beryllium $(25.03 \pm 0.86 \%)$, carbon (68.06 $\pm 1.09 \%)$, and oxygen $(6.01 \pm 0.36 \%)$. Though, aluminum, potassium, sodium, and silicon were present but in trace amounts. This contradicts the results of Aliero et al. [25] who reported that foliar crystals in some plants majorly composed of aluminum, potassium, sodium, and silicon. The high amount of carbon 


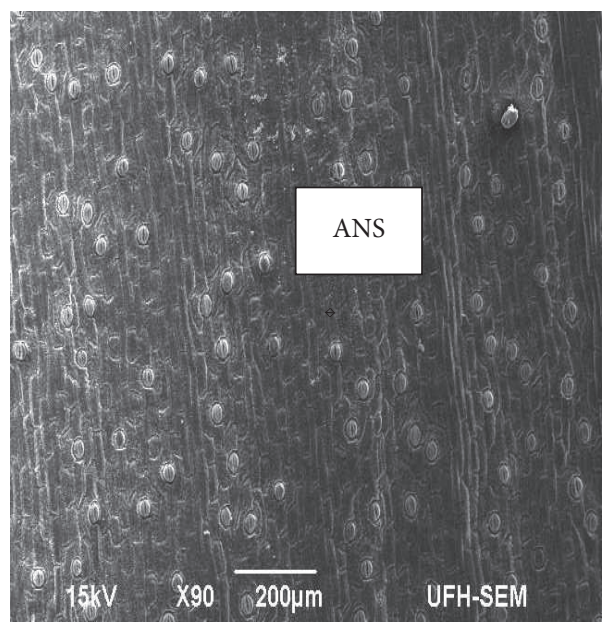

(a)

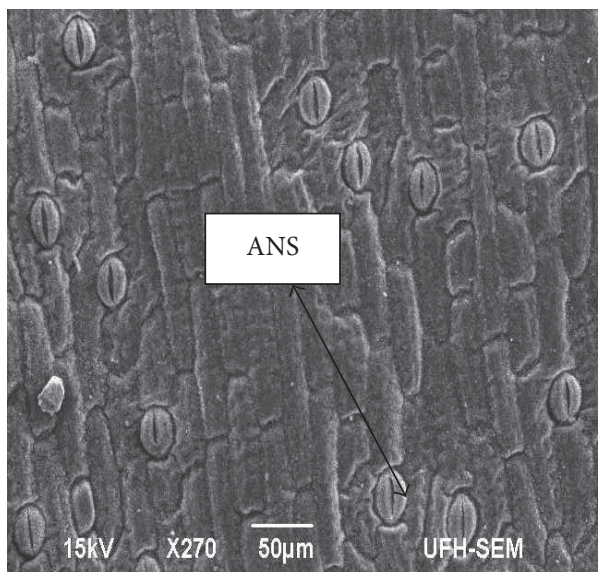

(c)

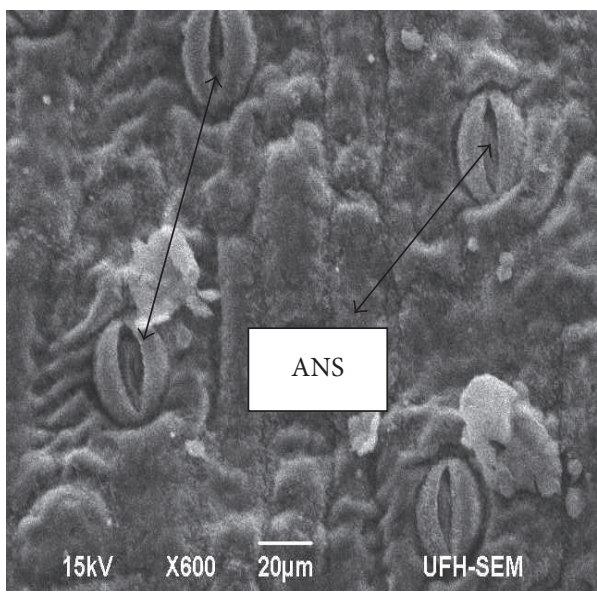

(e)

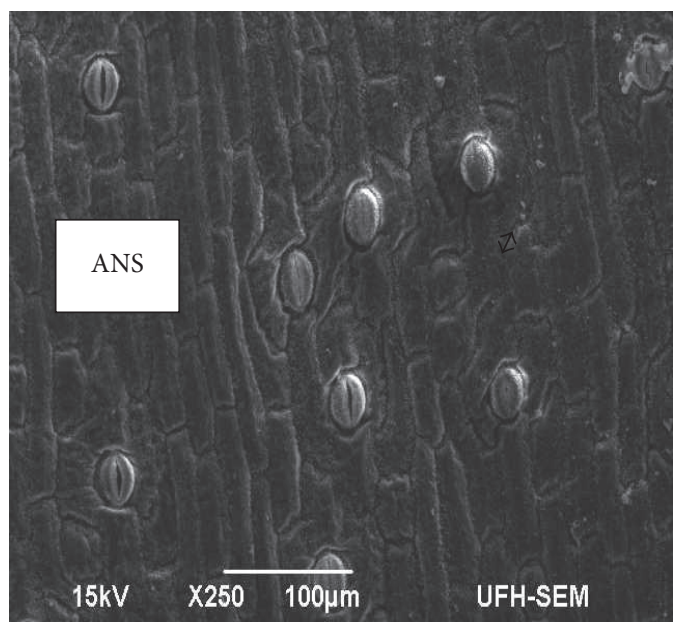

(b)

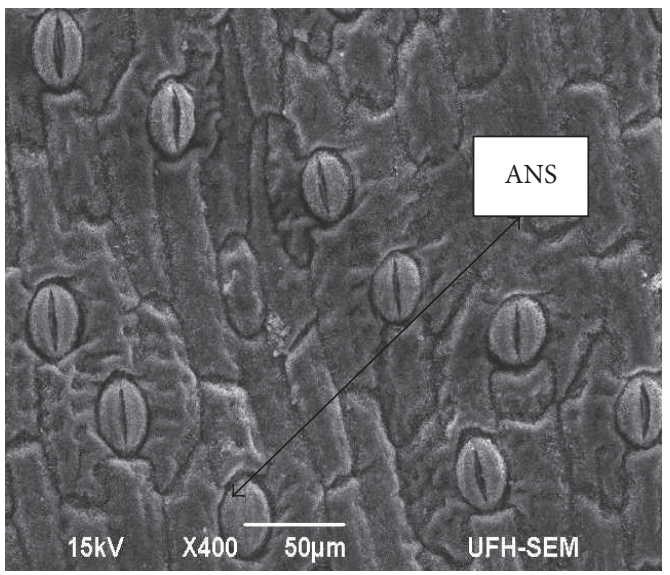

(d)

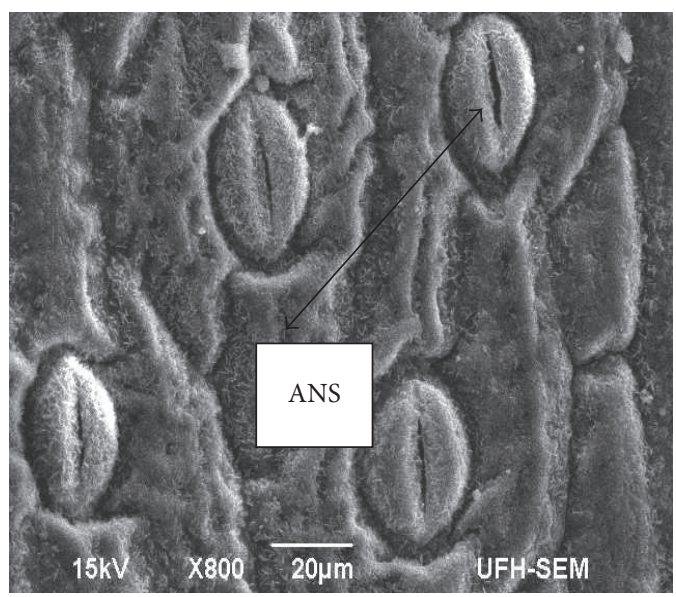

(f)

FIGURE 4: SEM micrographs (a-f) of abaxial epidermis of $A$. praecox subsp. praecox showing randomly arranged anomocytic stomata with open pores at different magnifications (ANS = anomocytic stomata). 


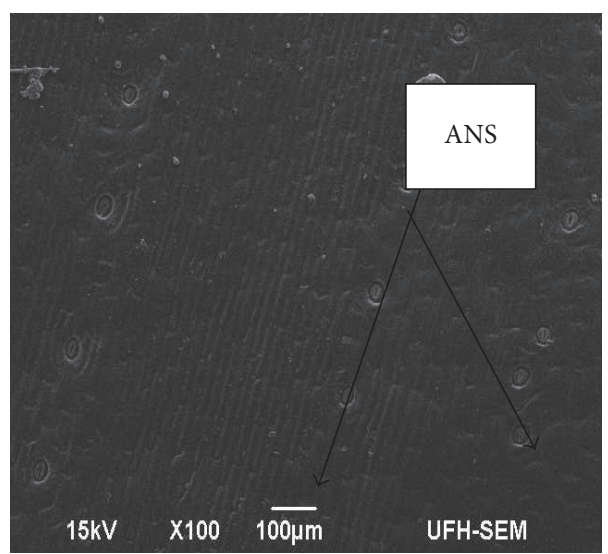

(a)

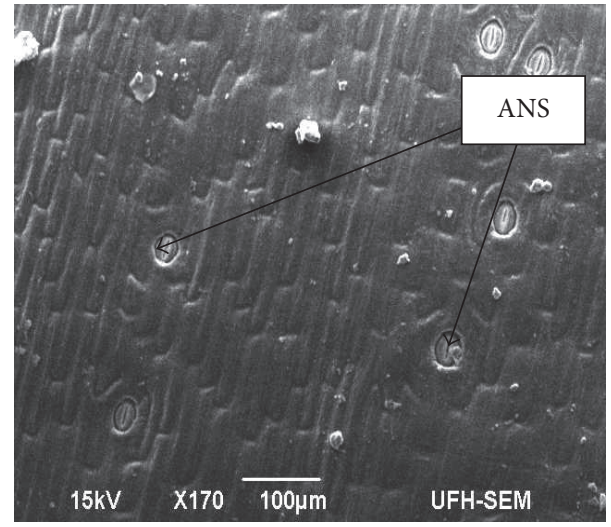

(c)

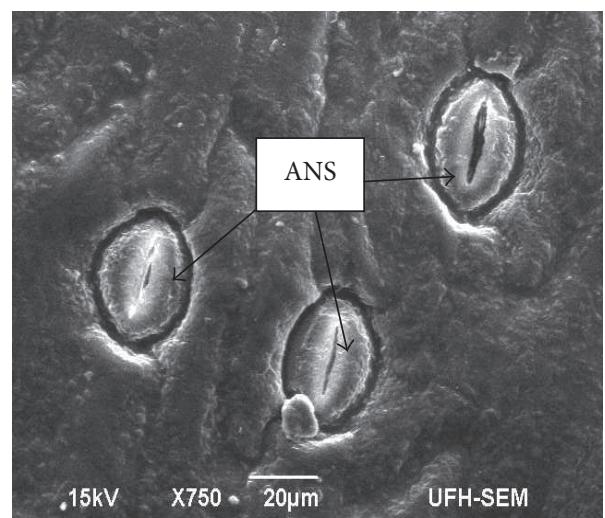

(e)

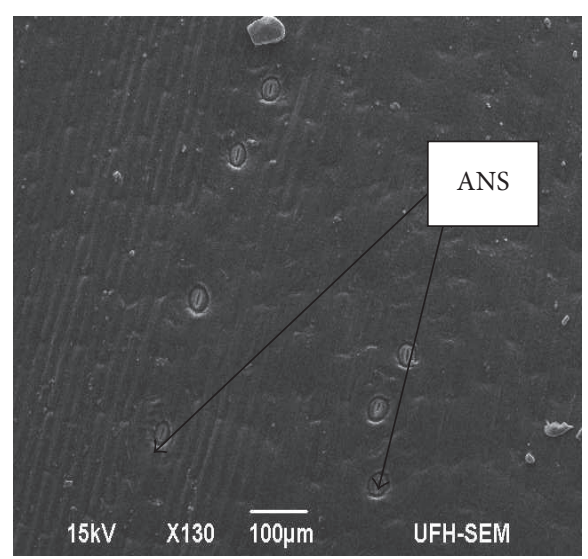

(b)

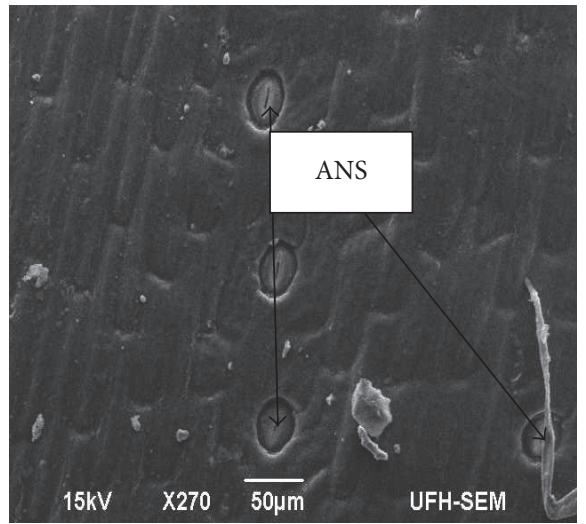

(d)

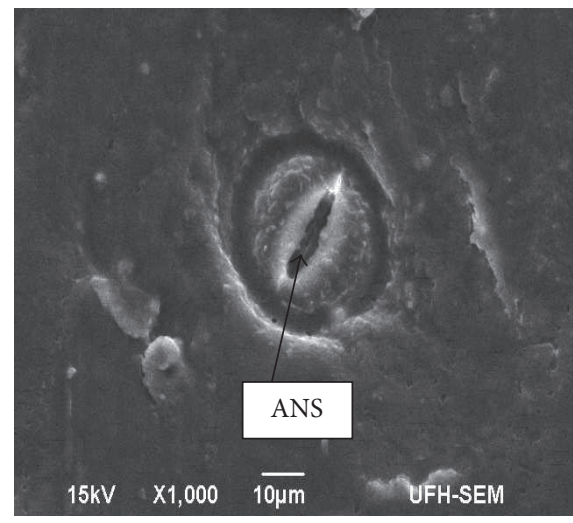

(f)

FIgURE 5: Scanning electron micrographs (a-f) of foliar adaxial epidermis of A. praecox subsp. praecox showing anomocytic stomata with open pores at different magnifications (ANS $=$ anomocytic stomata).

in the EDX spectra of both the leaves and rhizomes of $A$. praecox may be the source of strength observed in the babies fed with infusion of this plant. This study provides for the first time comprehensive micromorphological information of the leaves and rhizomes of Agapanthus praecox subsp. praecox.

\section{Conclusion}

This study is a positive step in resolving the taxonomic confusion that exists in the genus Agapanthus. The presence of anomocytic stomata, polygonal epidermal cells with wavy anticlinal walls, helical thickened vessels, and xylem tracheary elements with crystals as well as the absence of trichomes and secretory ducts in A. praecox subsp. praecox may be useful tools in the identification of this species from the closely related species of Agapanthus. Though, further comparative micromorphological studies within species of this genus are recommended; this study was able to provide information on the microcharacters of the leaves and rhizomes of A. praecox subsp. praecox. 


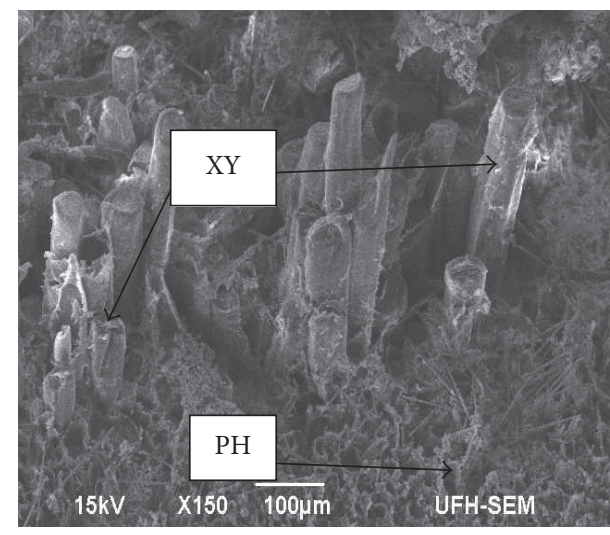

(a)

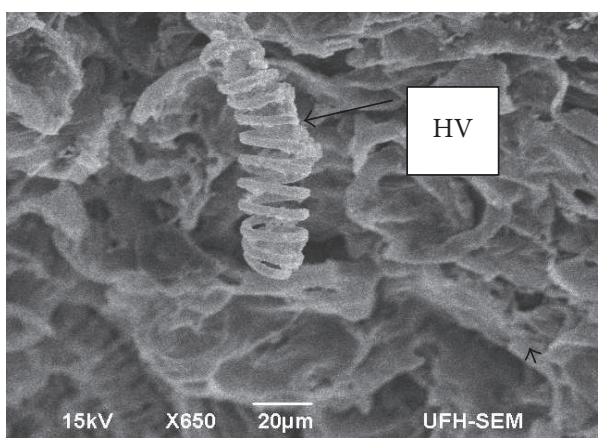

(c)

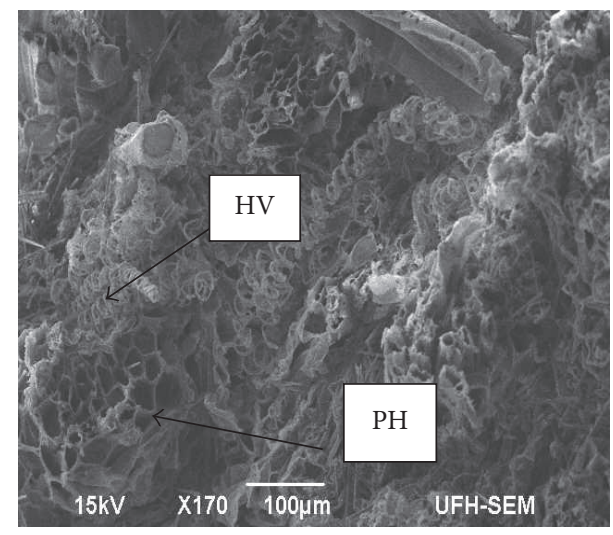

(b)

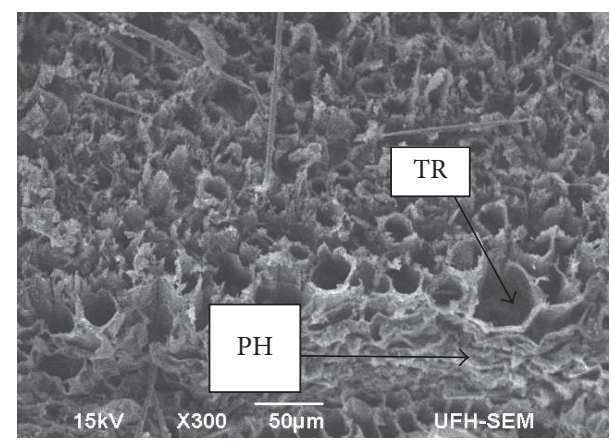

(d)

FIGURE 6: Scanning electron micrographs (a-d) of A. praecox subsp. praecox rhizome showing the xylem (XY), phloem (PH), tracheids (TR), and helical thickened vessels (HV).

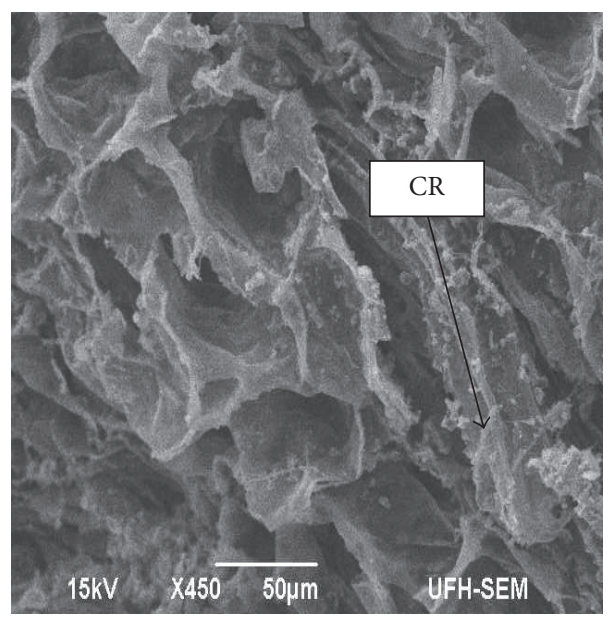

(a)

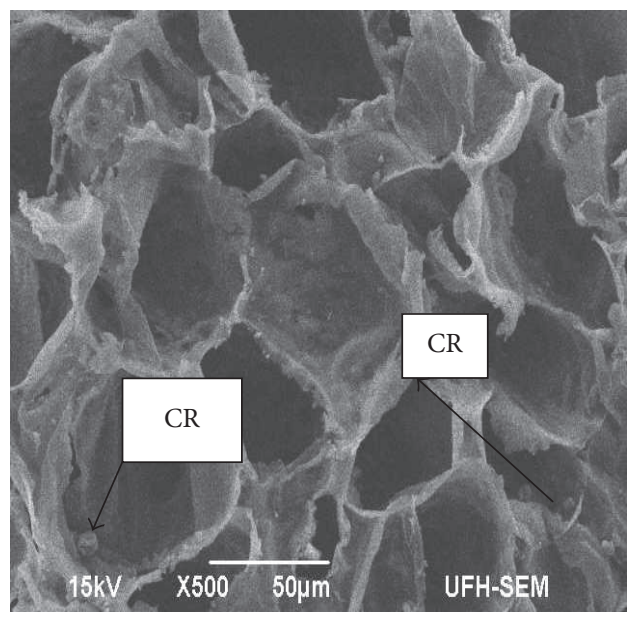

(b)

FIGURE 7: SEM micrographs of $A$. praecox subsp. praecox rhizome showing (a) crystal deposits around the tracheids and (b) the xylem vessel (CR = crystal deposits). 

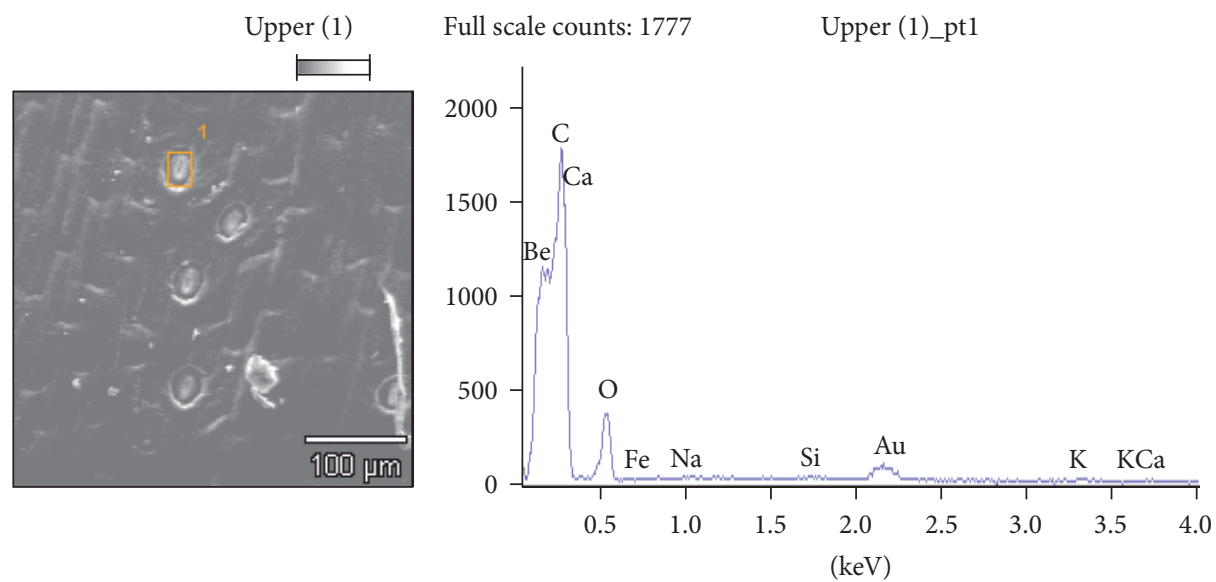

Lower (1)

Full scale counts: 1714

Lower (1)_pt1
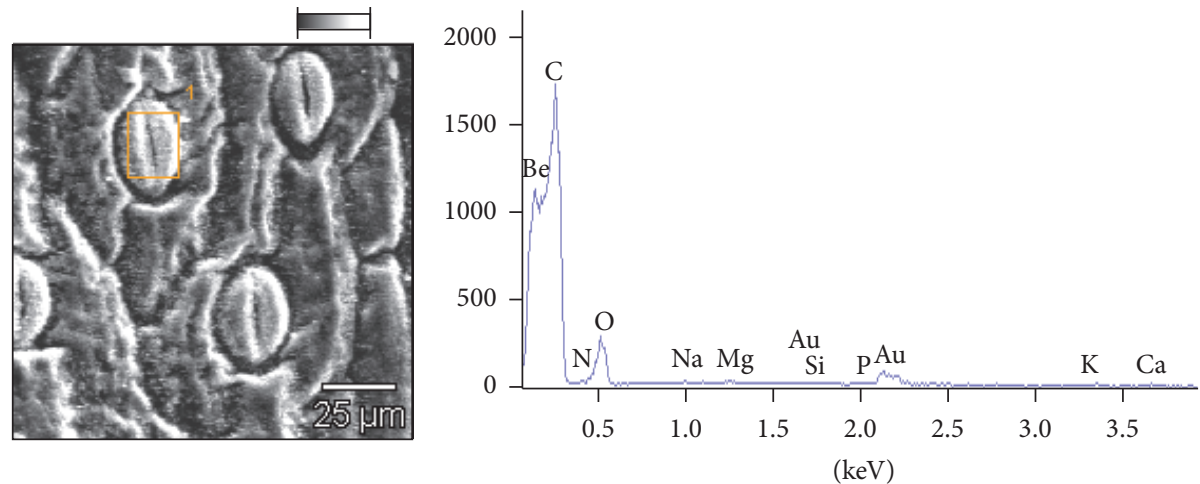

FIGURE 8: EDX photomicrographs and spectra of the adaxial (a) and abaxial epidermis (b) of A. praecox.

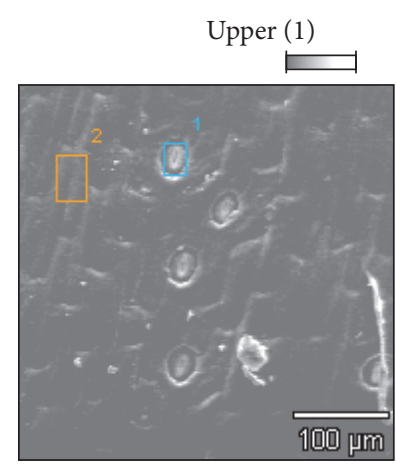

Full scale counts: 1573

Upper (1)_pt2
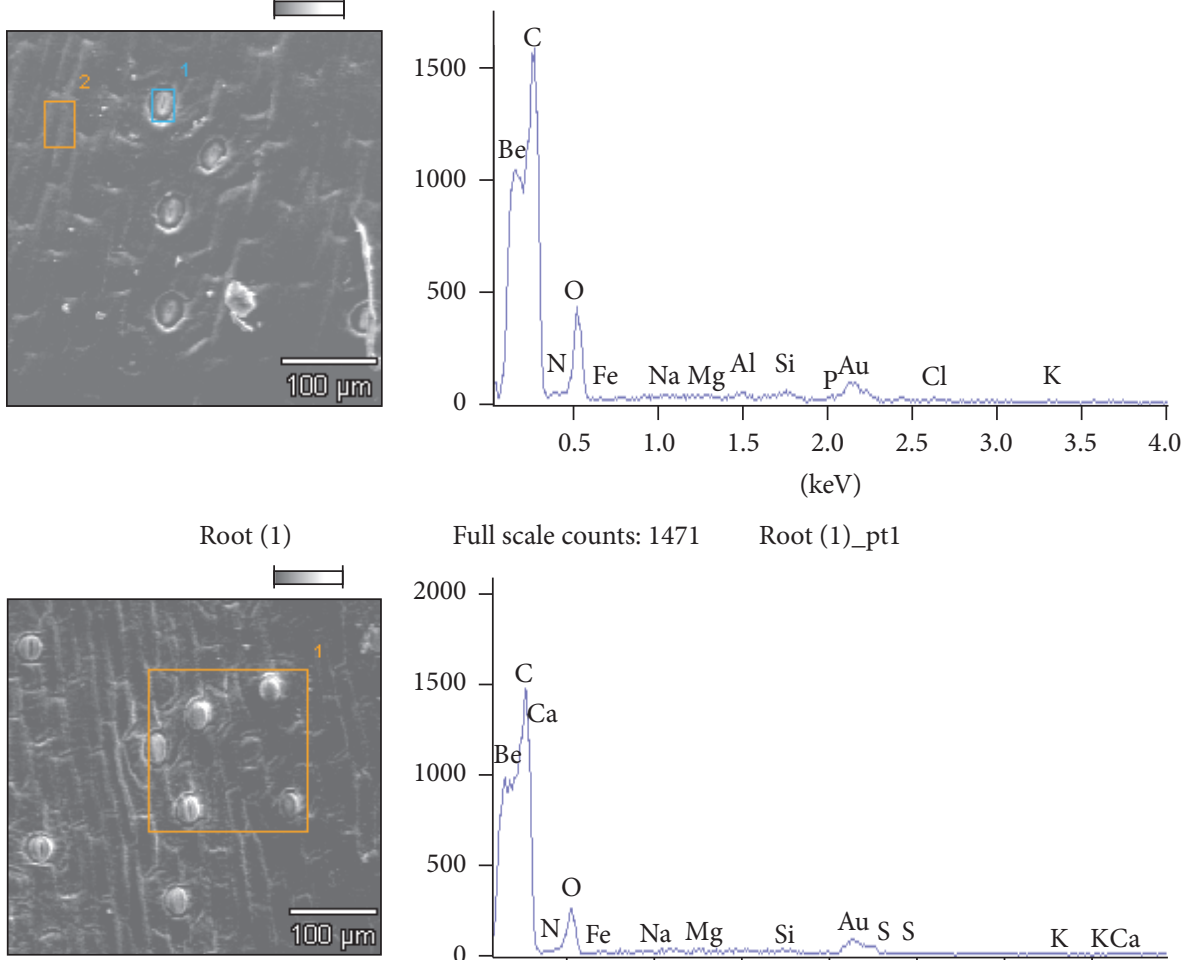

$$
\text { Full scale counts: } 1471 \quad \text { Root (1)_pt1 }
$$

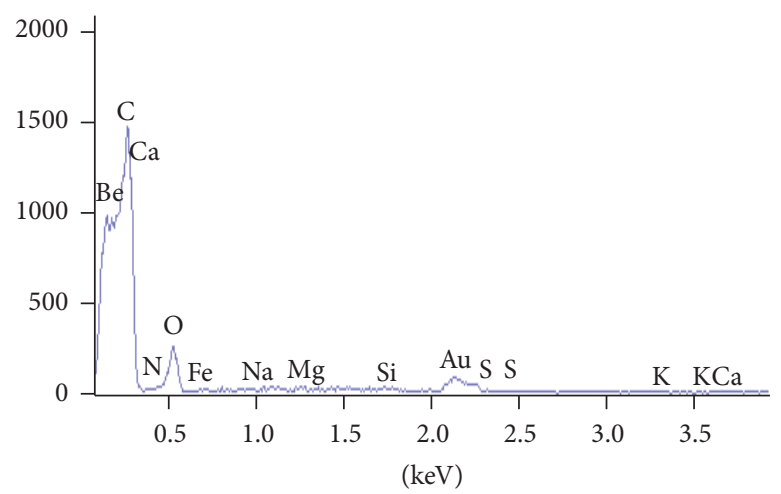

FIGURE 9: EDX photomicrographs and spectral of adaxial epidermis and rhizome of A. praecox. 


\section{Conflicts of Interest}

The authors declare that there are no conflicts of interest regarding the publication of this paper.

\section{Acknowledgments}

The authors acknowledge Govan Mbeki Research Development Centre, University of Fort Hare, South Africa, for the financial support.

\section{References}

[1] G. Duncan, Grow Agapanthus: A guide to the species, cultivation and propagationof the genusAgapanthus, National Botanical Institute, Trident Press, Cape Town, South Africa, 2002.

[2] F. M. Leighton, “The genus Agapanthus L'Hérit," Journal of South African Botany, vol. 4, pp. 1-50, 1965.

[3] B. J. M. Zonneveld and G. D. Duncan, "Taxonomic implications of genome size and pollen colour and vitality for species of Agapanthus L'Héritier (Agapanthaceae)," Plant Systematics and Evolution, vol. 241, no. 1-2, pp. 115-123, 2003.

[4] A. Notten, "gapanthus praecox Willd", PlantZAfrica.com South African National Biodiversity Institute, 2004.

[5] B.-E. Van Wyk, B. van Oudtshoorn, and N. Gericke, Medicinal Plants of South Africa, Briza Publications, Pretoria, South Africa, 2nd edition, 2013.

[6] C. A. Varga and D. J. H. Veale, "Isihlambezo: utilization patterns and potential health effects of pregnancy-related traditional herbal medicine," Social Science and Medicine, vol. 44, no. 7, pp. 911-924, 1997.

[7] A. P. Dold and M. L. Cocks, "Traditional veterinary medicine in the Alice district of the Eastern Cape Province, South Africa," South African Journal of Science, vol. 97, no. 9-10, pp. 375-379, 2001.

[8] W. Snoeijer, Agapanthus: A Revision of The Genus, Timber Publication Cambridge, 4th edition, 2004.

[9] S. Koduru, D. S. Grieson, and A. J. Afolayan, "Ethnobotanical information of medicinal plants used for treatment of cancer in the Eastern Cape Province," Current Science, vol. 92, pp. 97-99, 2007.

[10] E. Pooley, Mountain flowers: A field guide to the flora of the Drakensberg and Lesotho, The Flora Publications Trust, Durban, South Africa, 2003.

[11] G. I. Stafford, A. K. Jäger, and J. Van Staden, "Activity of traditional South African sedative and potentially CNS-acting plants in the GABA-benzodiazepine receptor assay," Journal of Ethnopharmacology, vol. 100, no. 1-2, pp. 210-215, 2005.

[12] World Health Organization, “Traditional Medicine: Growing Needs and Potential, WHOPolicy Perspectives on Medicines, World Health Organization, Geneva, 2002.

[13] M. A. Sonibare, T. A. Oke, and M. O. Soladoye, "A pharmacobotanical study of two medicinal species of Fabaceae," Asian Pacific Journal of Tropical Biomedicine, vol. 4, no. 2, pp. 131-136, 2014.

[14] T. F. Stuessy, Plant Taxonomy: The Systematic Evaluation of Comparative Data, Columbia University Press, New York, NY, USA, 2nd edition, 2009.

[15] A. Sofowora, Medicinal Plants And Traditional Medicine in Africa, John Wiley and Sons Ltd, Hoboken, NJ, USA, 2008.
[16] A. Bano, M. Ahmad, M. Zafar, S. Sultana, and M. A. Khan, "Comparative foliar micromorphological studies of some species of Asteraceae from alpine zone of Deosai plateau, Western Himalayas," Journal of Animal and Plant Sciences, vol. 25, no. 2, pp. 422-430, 2015.

[17] Z. I. El Sayed, A.-M. M. Ateya, and M. Fekry, "Macro- and micromorphological study of the leaf, stem, flower and root of Hibiscus rosa-sinensis L.", Journal of Applied Sciences Research, vol. 8, no. 1, pp. 34-56, 2012.

[18] J. H. Jones, "Evolution of the Fagaceae: The Implications of Foliar Features," Annals of the Missouri Botanical Garden, vol. 73, no. 2, p. 228, 1986.

[19] N. R. Da Silva, M. W. D. S. Oliveira, H. A. D. A. Filho et al., "Leaf epidermis images for robust identification of plants," Scientific Reports, vol. 6, article 25994, 2016.

[20] D. K. Awasthi, V. Kumar, and R. Rawat, "Stomatal studies in Amaryllidaceae with special reference to stomatal abnormalities," Proceedings: Plant Sciences, vol. 93, no. 6, pp. 629-633, 1984.

[21] A. O. T. Ashafa, D. S. Grierson, and A. J. Afolayan, "Foliar micromorphology of Felicia muricata Thunb., a South African medicinal plant," Pakistan Journal of Biological Sciences, vol. 11, no. 13, pp. 1713-1717, 2008.

[22] S. Koduru, D. S. Grierson, and A. J. Afolayan, "The foliar micromorphology of Solanum aculeastrum, a medicinal plant of South Africa," Pakistan Journal of Biological Sciences, vol. 9, no. 6, pp. 1056-1060, 2006.

[23] N. R. Lersten and H. T. Horner, "Crystal macropatterns in leaves of Fagaceae and Nothofagaceae: A comparative study," Plant Systematics and Evolution, vol. 271, no. 3-4, pp. 239-253, 2008.

[24] P. A. Nakata, "Plant calcium oxalate crystal formation, function, and its impact on human health," Frontiers in Biology, vol. 7, no. 3, pp. 254-266, 2012.

[25] A. A. Aliero, D. S. Grierson, and A. J. Afolayan, "The foliar micromorphology of Solanum pseudocapsicum," Flora: Morphology, Distribution, Functional Ecology of Plants, vol. 201, no. 4, pp. 326-330, 2006. 

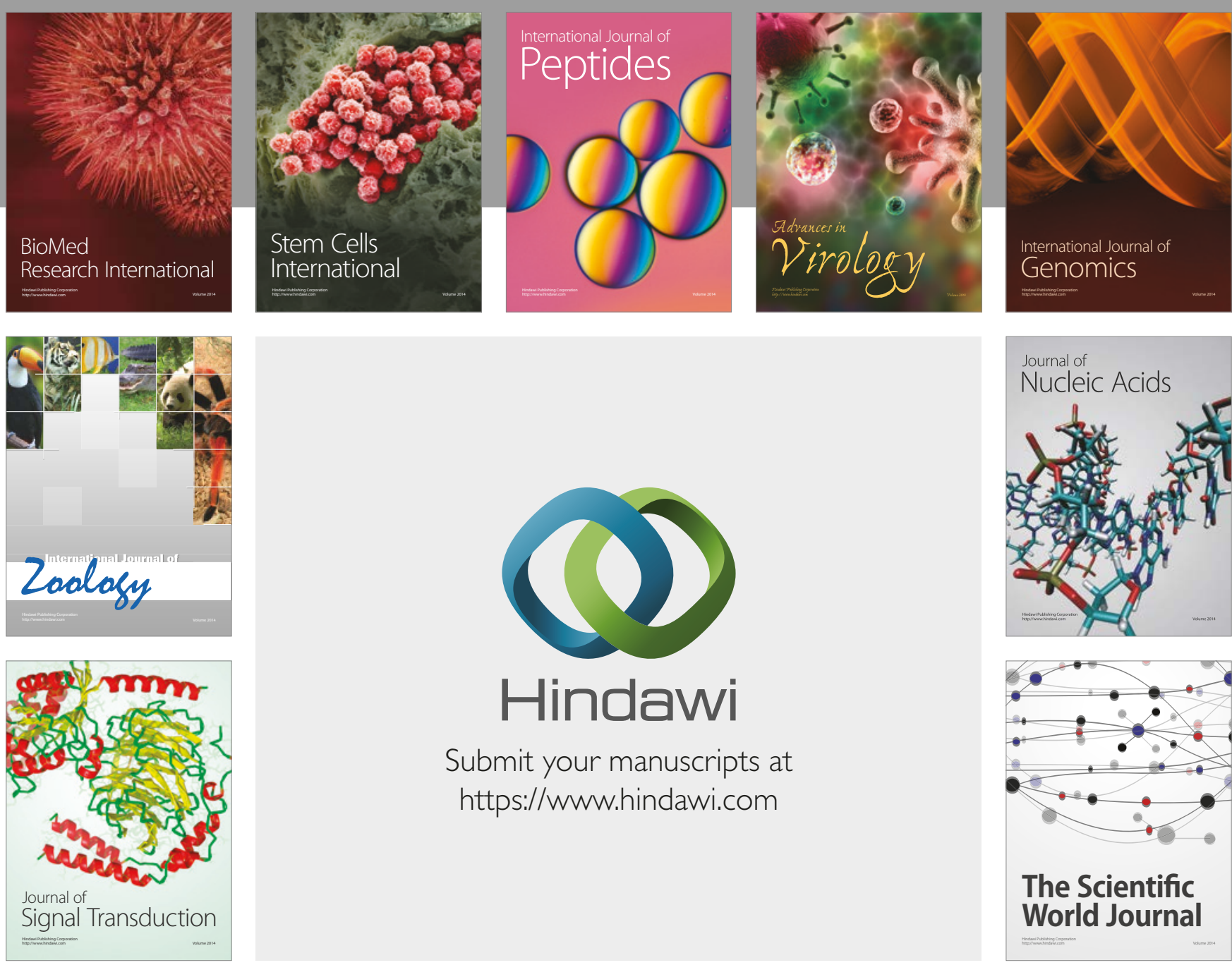

Submit your manuscripts at

https://www.hindawi.com
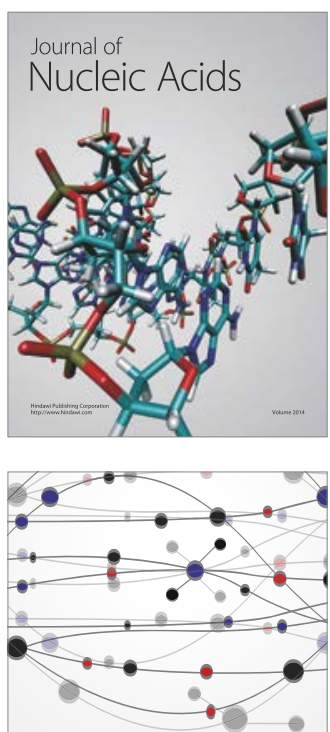

The Scientific World Journal

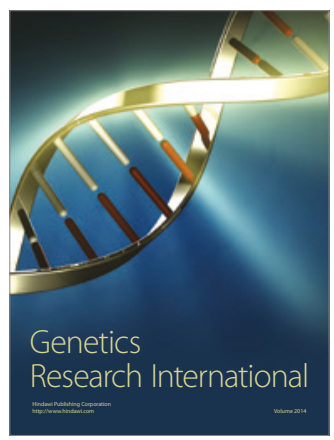

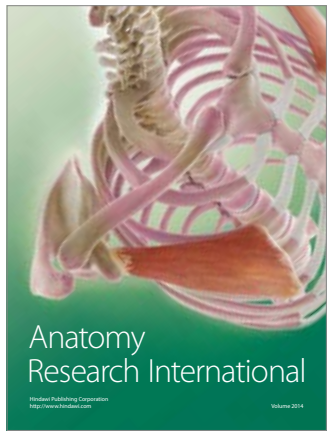

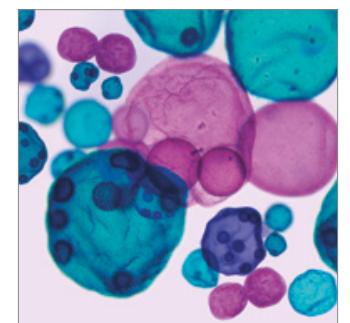

International Journal of Microbiology
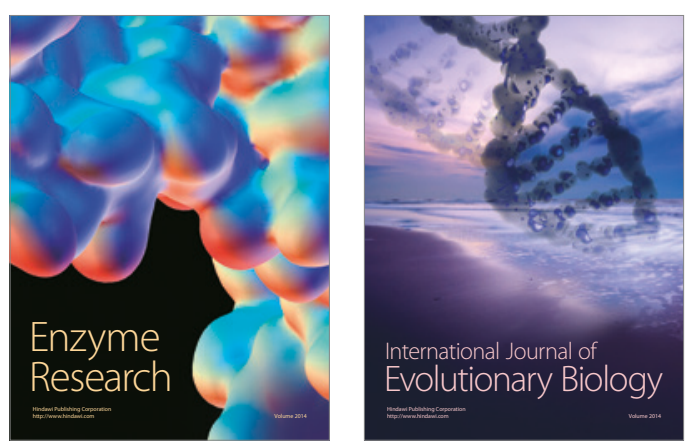
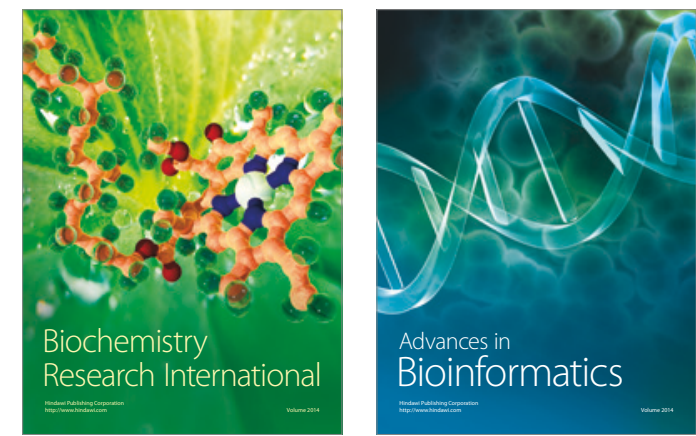

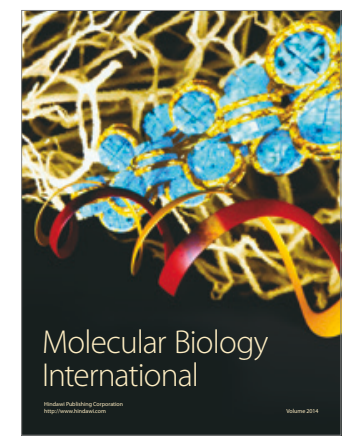

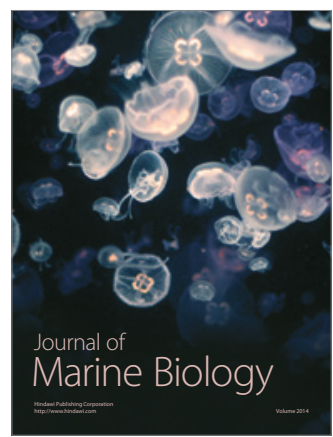

